Dialectologia 24 (2020), 1-21.

ISSN: 2013-2247

Received 15 March 2018.

Accepted 30 June 2018.

\title{
SOCIO-POLITICAL LANGUAGE USE AND YORÙBÁ PROTEST SONGS: A STYLISTIC APPROACH
}

\author{
Dayọ̀ ÀKÀNMÚ \\ Adéníran Ògúnsànyà College of Education * \\ dayoakanmu2002@yahoo.com
}

\begin{abstract}
Song is a universal phenomenon and significant aspect of Yorùbá literature usually constructed systematically using words that reflect either negative or positive linguistic connotation. Existing studies established their scope of usage in several areas of endeavors but have hardly addressed their negative implication for using them in socio-political scenario of Nigeria which sometimes seems to be counterproductive and having overbearing effect on peace and stability of the Nation. The paper adopts Marxist theory for its ability to explain reason for political and economic crisis in government and what the oppressed members of society must do to liberate themselves from such crisis. Eight protest songs were purposively selected from the Nigerian political scenario of the past for having sufficient usage of the Yorùbá protest songs imbued with curse, hate expressions, abuse, derision and ridicule/sarcasm. In order to strike a balance, four corrupt coinages of the Christian songs and the other four corrupt coinages of the Yorùbá traditional songs were eventually subjected to stylistic analysis. In all, politics, financial fraud and jubilation were expressed and contextualized in curse, ridicule/sarcasm, derision, hatred and abusive utterances all of which are capable of destabilizing peace and unity of the country. Yoruba protest songs in this paper are corrupt coinages of both Christian and Yorùbá traditional songs used to express sociopolitical issues in Nigeria and conveyed through curse, hate expressions, derision, sarcasm, abusive utterances and also reflect ingenuity-constrained stylistic choices.
\end{abstract}

* School of Languages, Adéníran Ògúnsànyà College of Education, Ọ̀tọ̀/lijanikin, P.M.B. 007, FESTAC Town, Lagos, Nigeria. 


\section{Keywords}

Yoruba, protest songs, stylistic, socio-political, ingenuity, hate expressions

\section{EL USO DEL LENGUAJE SOCIOPOLÍTICO Y LAS CANCIONES DE PROTESTA EN YORÙBÁ: UN ENFOQUE ESTILÍSTICO}

\section{Resumen}

La canción es un fenómeno universal y un aspecto significativo de la literatura yorùbá, generalmente construida sistemáticamente utilizando palabras que reflejan una connotación lingüística negativa o positiva. Los estudios existentes establecieron su alcance de uso en varias áreas, pero apenas han abordado su implicación negativa para usarlos en el escenario sociopolítico de Nigeria, que a veces parece ser contraproducente y tener un efecto despótico sobre la paz y la estabilidad de la nación. El artículo adopta la teoría marxista por su capacidad para explicar la razón de la crisis política y económica en el gobierno y lo que los miembros oprimidos de la sociedad deben hacer para liberarse de dicha crisis. Ocho canciones de protesta se han seleccionado deliberadamente del escenario político nigeriano del pasado por tratarse de canciones de protesta en Yorùbá imbuidas de maldiciones, expresiones de odio, abuso, burla y ridículo/sarcasmo. Para lograr un equilibrio, cuatro acuñaciones corruptas de las canciones cristianas y las otras cuatro acuñaciones corruptas de las canciones tradicionales de Yorùbá se han sometidas a un análisis estilístico. En general, la política, el fraude financiero y el júbilo se expresaron y contextualizaron en forma de maldiciones, ridículo/sarcasmos, burlas, odios y expresiones abusivas, los cuales son capaces de desestabilizar la paz y la unidad del país. Las canciones de protesta en yoruba son tanto acuñaciones corruptas de canciones tradicionales cristianas como en yorùbá utilizadas para expresar problemas sociopolíticos en Nigeria y transmitidas a través de maldiciones, expresiones de odio, burla, sarcasmo, expresiones abusivas y también reflejan elecciones estilísticas limitadas por el ingenio.

\section{Palabras clave}

Yoruba, canciones de protesta, estilísticas, sociopolítica, ingenio, expresiones de odio

\section{Introduction}

Song, a fundamental aspect of Yorùbá literature is not strange to the Yorùbá people and cannot be separated from the politics of Nigeria in as much as Yorùbá retains its position as one of the three major ethnic groups in Nigeria. Song is so unique in the 
Nigerian political history that it has enjoyed a robust attention and coverage by literary scholars like Ọlábímtán (1978), Owólabí (1988), Fálétí (1969), Akínlàdé (1985).

Politics or governance, on the other hand, is a symbiotic relationship between the government and the governed in form of 'input' and 'output' in a way that the output determines the input. Every decision or policy of government is given reaction by the citizens either positively or negatively. When a policy is accepted, the people applaud and embrace government with positive comments but when it is otherwise, citizens express their displeasure, sometimes with negative comments and protest for reversal of any obnoxious policy.

In the atmosphere of protest, protest songs usually come with different ingenious renditions from the Trade Unions, Staff Unions, Students' Union and Civil Society Groups to press home their demands or register their displeasure against obnoxious decisions and policies of the government. Protest song of this nature sometimes, leads to political unrest and political instability, especially when negative use of language such as hate expressions and curses are involved.

Before now, in Yorùbá culture to be precise, singers and performers of any verbal arts are always protected from the judicial prosecution even when negative and direct references are made to important personalities or those in position of authority as reflected in the expression "máa wí ọba kì pọkọrin" (speak on, king never killed the oral artist). This traditional immunity encouraged singers and other verbal performers or oral artists to lampoon and criticize excesses and abuse of power of those in authority because of the high moral standard operated in the Yorùbá society of the past. As recorded in history, this high moral value necessitated the suicidal mission embarked upon by one Aláàfin Jáyìn before the arrival of the iwì chanters who wanted to expose his atrocities through iwì. This scenario also has a place in Yorùbá proverb that says 'ó kù dẹdẹ ká gbéwì d'Ákèsán Aláàfin Jáyìn tẹrí gbașọ' (before iwi chanters arrived Akèsán, king Jáyìn gave up the ghost). Song, especially of protest, is meant to effect behavioural change or action in a person to whom it is intended. For instance, in one of Fágúnwà's prominent books, Igbó Olódùmarè (1949) to be precise, Olówó Ayé and Èșù Kékeré Òde 
engaged in a fierce battle and Olówó Ayé defeated him using song capable of inducing a compromising and peaceful mood.

If this aforementioned song is compared to the protest songs imbued with curse, derision, and hate expressions rendered by the Trade Unions, Staff Unions, Students' Unions and Civil Society Groups in the society of today (where moral standard is ridiculously low) what would have been the result? The answer to this question in reference to the popular Yoruba proverb “ọ̀rọ̀ ló ń yọ obì nínú àpò, ọ̀rọ náà ló ń yọ idà nínú àkọ̀" (good expression draws kola nut (gift) from the pocket while bad word draws sword from its sheath) is what this paper sets out to address.

\section{Method of Data Collection}

Data for this paper were purposively drawn from the protest songs used in the past by the Nigerian Labour Congress, Staff Unions, Students' Unions and other Civil Society Groups during some of the Nation's political unrests. In order to strike a balance, eight of the said protest songs imbued with curse, derision, sarcasm and hate expressions were analysed (four corrupt coinages of the Christian songs and the other four corrupt coinages of the Yorùbá traditional songs) all were subjected to stylistic analysis with a view to establishing their negative implication on peace and tranquility of Nigeria.

\section{Marxist Theory}

The theory adopted for this paper is the Marxist theory propounded by Karl Marx in (1818-1833), Engels (1820-1895) and developed by their followers, especially Caudwell (1937) and others who used it for analyzing literary works. The theory is employed because of its ability to explain reason for political and economic crisis in government and what the oppressed must do to liberate themselves from such crisis. The theory sees literary work as illumination of class interest, where literature is fundamentally conditioned by socio-political indices under which the downtrodden and exploited 
members of the society are liberated. According to Karl Marx, man has been a slave of the extraneous economic forces, religious, philosophical and political illusions and that the emancipation of individual, especially the oppressed from their miserable condition under the capitalist system into a resuscitating social system is sacrosanct. Marxist theory emphasizes much on literature and society. This must have been the reason Davignaud (1977), and Caudwell (1977) cited in Adéyẹmí (2006: 39) aver that relationship between literature and society is uppermost not only in the heart of Karl Marx but also his followers. To them, literature can be in contrary to policy and ideology of a society as well as being in support.

The theory, however, recommends that a literary critic must see himself as someone who has mandate to adequately criticize a particular literary text in order to know if the literary artist is in support or pushing for the transformation of policy and ideology of a particular society. Going by the aforementioned, it can be said that, although, the theory provides ingredients for analysing Yorùbá protest songs against government's bad policy and for liberation of the oppressed, but this paper contends that protest songs which involve the use of curse and hate expressions are not corrective measure and can be counterproductive and disrupt peace and tranquility of the society as it is in the hypothetical example below:

1) Ọ́mọ́ wọ́n ma kú
Ọmọ́ wọ́n ma kú
Àwọn tó pa Lágbájá
Tọ́n ọ̀n jẹ ó dàgbà o
Ọmọ́ wọ́n ma kú.
Their child will die
Their child will die
Those who killed Lágbájá
And deprived him of longevity
Their child will die.

The above is a typical example of a protest song with the use of curse directed at the suspected killer by the Civil Society Groups. In most cases, the song is directed to the 
government of the day whenever a murder case appears like a State killing. The expression 'máa kú' (will die) is a use of language that is not only derogatory but also magical and has certain negative spiritual order because of the power attached to tongue.

In Nigeria, the protesters always mention the name of the Head of Government under which such murder case is perpetrated instead of 'Lágbájá' in the above example. Although, in the past, several murder cases were speculated to have been linked to many previous regimes, no single person has been brought to book. The implication of this is that, since those murder cases could not be traced to anybody, the suspect (Head of State/President) mentioned in the song is innocent and could react using his authority negatively too thereby leading to further crisis. Analysis of this nature and many more are executed in this paper to give a clearer picture of how such protest songs can be counterproductive and lead to instability and disharmony in the society through the use of language.

\section{Scholarly Views on Song and Protest Song}

Generally speaking, scholarly works abound on song in Yorùbá studies but few are enumerated in this section of the paper. Some scholars have described song as a way of life of the Yoruba people accompanied by a great deal of impromptu singing for reporting, commenting, criticizing and harnessing public opinion (Bier 1956; Finnegan 1977; Ọlátúnjí 1984; Ògúndèjì 1991; Àlàbá 1992; Adégbìtẹ 1994; Agbájé 1995 and Adédèjì 2004).

Some other scholars are of the view that song is self-creative, ingenious, melodious and belong to a subcategory of oral Yorùbá poetry distinguished by its musical mode of rendition different from the recitative mode. To scholars in this category, song can be used for national development in terms of social, health and political expressions; psychological power of relieving tension as well as activation of emotional intensities (Bộlárìnwá 2016; Ọláníyan 2004; Ajíbádé 2011; Èésúolá 2012 and Orímóògùnjẹe 2014).

Based on the aforementioned views, it can be said that song is another means by which people express their views on any issue apart from using other forms of mundane communication. In other words, song can be used indirectly or in a limited and 
conventional manner to express what could not have been said directly, or through a different medium, or on just occasion; of upholding or suggesting certain values that cannot be expressed in other ways, especially when there is no direct access to political activity.

Protest song is a type of song used not by the Yorùbá people alone but by other tribes of the world where governance is sacrosanct, but misrule is the order of the day. In most cases, protest songs are used by the Trade Unions, Civil Society Groups and some other members of the society to harness and channel public opinion on various issues affecting the society, especially those that are artificially created through government's obnoxious policies. Protest song has potentiality for developing consciousness among the oppressed group of a particular country, while on the other hand, for the group in dominance. It is an extra tool for concretizing hegemony (Ọláníyan 2004: 5).

Indeed, songs are perceived to play the role of protest, resistance and revolt as corroborated by the Marxist theory adopted for this paper. But it is also important to yield to Plato's warning that "Any musical innovation is full of danger to the whole state and ought to be prohibited because when mode of song/music changes, the fundamental laws of the state always change with them". This view is not only very instructive but also germane to the purpose of this paper which is not against the protest songs but indifferent to certain negative and derogatory language involved in them because they are perceived to be dangerous, counterproductive and can lead to crisis.

\section{Analysis of selected Yorùbá protest songs}

As discussed earlier, few selected protest songs used previously by the Trade Unions, Staff Unions, Student Unions and other Civil Society Groups during some of the Nation's political unrests are subjected to stylistic analysis in this section. For instance, in 2012, Nigeria witnessed a massive protest tagged "Occupy Nigeria" organized by the 'Safe Nigeria Group' and the 'Enough is Enough Group' in response to the fuel subsidy removal by the Federal Government of president Goodluck Jonathan on Sunday, 1st January 2012. 
The action consequently led to untold hardship on the poor masses who could not but joined other protesters, singing the following protest songs:

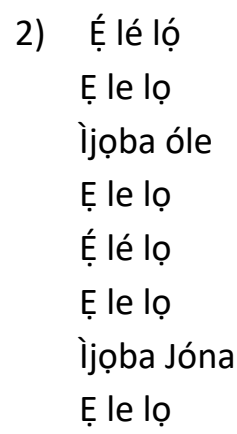

Drive it away

Send it packing

The government of thieves

Drive it away

Send packing the government of Jonathan

The above is one of the Yorùbá protest songs rendered at the freedom park, Ojọtta by coalition of Civil Society Groups on January $1^{\text {st }}, 2012$ in response to the fuel subsidy removal by the Government of President Goodluck Jonathan. The message of the song is very instructive as the protesters demanded for nothing but removal of president Jonathan and his cabinet. The language used in the song is not only abusive but also derogatory and dehumanizing, especially to the personality of a sitting president of the Federal Republic of Nigeria. For instance, the use of the expression Olè (thief) in İjọa Olè, e le lo ('Drive away the government of thieves') is highly despicable and capable of reducing president Jonathan's dignity to zero, especially when his action is viewed from the perspective of human error. If it is so, it is out of culture to use the expression ole (thief) which an average Yorùbá detests and sees as height of abusive utterances, for the president of the most populous black race in the world, except he is a real thief.

It is true that the Trade Unions, Civil Society Groups and other protesters have the constitutional backing to express themselves freely, even as the Marxist theory adopted for this paper emphasizes reason to express contrary opinion to any policy of government that can hinder people's well-being, it should be stressed here also that right to freedom of speech is not absolute as spelt out in section 45 of the 1999 Constitution of Nigeria. 
The section stands clearly in defense of other person's right. This means that the protesters' rights to freedom of speech stopped where the president's own starts. Apart from that, any song of this nature, which is tantamount to hate expressions, may not go down well with the president and his loyalists who may want to take it personal and advise the president to descend on such protesters thereby disrupting peace and stability of the country the more. Also, at the park, a prominent Christian song which says:

3) O ti mú mi gbàgbé o

Ìbànújẹ igbà kan

O ti mú mi gbàgbé o

Ìbànújẹ igbà kan

À șé wẹerẹ nișẹ olúwa

Ò̀ba tí mo pè tó ń jẹ

À șé wẹ́rẹ nișẹe Olúwa

ọ̀ba tí mo pè tó ń jẹ

He has made me to forget

The melancholy of the past

He has made me to forget

The sorrow of the past

Alas, God's work is effortless

The king, who answered when I call

Indeed, God's work is undemanding

The king, who answered when I call

is corrupted to lampoon and ridicule President Jonathan thus:

4) O ti yára gbàgbé o

Ìlerí rẹ ìgba kan

$O$ ti yára gbàgbé $o$

Ìlerí rẹ ìgba kan

Jonathan!

À șé bíntín lọgbọ́n orí rẹ İwọ tí a rò pó gbọ́n

À șé bíńtín lọgbộn orí rẹ

İwọ tí a rò pó gbọ́n 


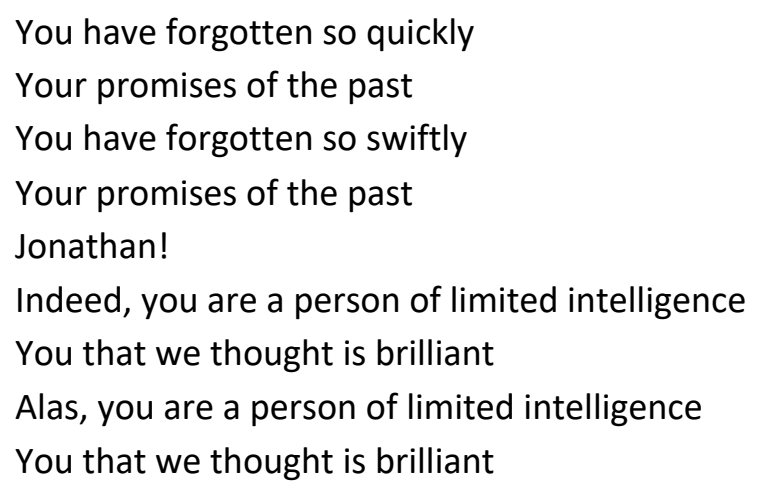

The above is a corrupt coinage of a popular Christian song earlier highlighted above. Looking at the song critically, it is an expression of politics in the context of abuse, derision and ridicule. For whatever reason, it is abusive to refer to the caliber of president Jonathan as a a personality of little or no intellect "à șé bíntín lọgbọ́n orí ẹ" ('indeed, you are a person of limited intelligence'). Linguistically, the word bińtín is a phonaesthetic idiophone where the sound of an expression suggests its meaning. In this context, bíntín ('little') can be interpreted to mean 'very light, insignificant, empty, extremely low' and when all these are used to qualify the intellect of a sitting president of a country like Nigeria, it is nothing but the height of ridicule and absurdity.

The abusive language in the song is capable of demystifying and reducing the position of the president into nothing, especially with the use of expression, like iwo tí a rò pó gbọ́n ('you that we thought is brilliant'). This particular line is ingeniously composed by the Fújì icon, Alhaji Kollington Àyìnlá who rendered the song at the park to expose President Jonathan's failure as the only Nigerian president ever with a degree of Doctor of Philosophy and to prove that higher degree does not translate to competence in governance. Here is a song of praise originally used by the Christians to show appreciation for great things God has done in their lives now recomposed to lampoon and ridicule president Jonathan. In the song of praise, O ti mú mi gbàgbé ('He has made me to forget') is corrupted as $O$ ti yára gbàgbé ('you have quickly forgotten'), ìbànújẹ ìgbà kan ('melancholy of the pas't), as ilérí rẹ igbà kan ('your promises of the past'), à șé wẹrẹe niṣé Olúwa ('Alas, God's work is effortless') as à șé bíntín loggộn orí rẹ ('Alas, you are a person of limited intelligence'), Ọa tí mo pè tó ń jẹ ('the king who answered when I call') as ìwo tí a rò pó gbọ́n ('you that we thought is brilliant') respectively. The Fújì icon is so skillful in 
the composition of the song that no single line of his corrupt composition is contrary to the original in terms of rhythm, melody, tone and rhyme. As a matter of fact, audience who were watching the protest live on the African Independent Television (AIT) and Television Continental (TVC) must have carefully listened to the song at the second attempt to notice that the song is corrupted.

It should be stressed here also that, the use of language of this nature is not in any way different from the several hate speeches on social media against the incumbent president of Nigeria which has almost destabilized the entire nation and might be counterproductive to or disrupt the peace and stability of the country in future if it is not curtailed. In another instance, at the same park, members of the Civil Society Group anchoring the "Occupy Nigeria" corrupted another Christian song which says:

5) Áwá yó ma yìn ó

Áwá yó ma gbé ọ ga

Íwọ́ șá ma șàtilệyìn wa

Áwá yó ma gbé ọ ga

We shall continue to praise you

We shall continue to lift you up

And you just continue to support us

We shall continue to uplift you

as:

6) Jonathan ti șè wá

Jonathan ti fọ́wa je

Gbógbó wá ti padà lẹyin rẹ

Ómí ló ma gbé o lo

Jonathan has offended us

Jonathan has disappointed us

We have all turned against you

You will drown in the ocean

The above which expresses the use of 'èpè' (curse) is an ingenious corrupt composition of another Christian song used in place of a protest song in terms of rhythm, melody, and rhyme. This is made possible because of the phonological, similarities of the 
two songs. There is no difference in the tone of every word in each of the lines of the two songs. For instance, the tone on the expression below:

\author{
7) Áwá yó ma yìn ọ \\ (we shall continue to praise you)
}

which is the combination of high tone + high tone + high tone + mid tone + low tone + high $(\mathrm{H}+\mathrm{H}+\mathrm{H}+\mathrm{M}+\mathrm{L}+\mathrm{H})$ and which sounds thus:

mí mí mí re dò mí

is the same tone on the first line of the corrupted version.

Jónáthán ti șẹ̀ wá

The situation is not in any way different from what we have in other lines which also exhibits phonological similarity. This makes the corrupted version very interesting to hear and listen to because people who are listening for the very first time will feel that it is the same Christian song they are familiar with until they start hearing expression like fọ́wa jẹ ('disappointed us'), șẹ wá ('offend us') and omi ló máa gbé o lọ ('you will drown in the ocean'). All these expressions are corrupt versions of words like yìn ọ́ ('praise you'), gbé o ga ('uplift you') and ìwo șá máa șàtilẹ́yin wa ('and you just continue to support us') in the real Christian song which is purposely used to appreciate God for all the good He has done.

In other words, the two songs (the original and the corrupted), enjoy some beautiful tonal variations which have phonological and semantic implications. On the phonological plane, both songs are tonemically corresponding. The tonal structure is presented in table 1 below where ' $L$ ' represents line of song(s); the numeral accompany each ' $L$ ' indicates the line concern (whether the first, second...) ' $x$ ' stands for absence and ' $\checkmark$ ' indicates presence. 


\begin{tabular}{|l|c|c|c|c|c|c|}
\hline & H & M & (L) & H & (M) & (L) \\
\hline L1 & $\checkmark$ & $\checkmark$ & $\checkmark$ & $\checkmark$ & X & X \\
\hline L2 & $\checkmark$ & $\checkmark$ & X & $\checkmark$ & $\checkmark$ & X \\
\hline L3 & $\checkmark$ & $\checkmark$ & $\checkmark$ & $\checkmark$ & $\checkmark$ & $\checkmark$ \\
\hline L4 & $\checkmark$ & $\checkmark$ & X & $\checkmark$ & $\checkmark$ & X \\
\hline
\end{tabular}

Table 1. Tonal Pattern/Frequency of the Song

From the table, we observe that some tones are optional or irregular while others are obligatory or constant. The irregular tones are put in brackets, but the constant tones are not. Out of the irregular tones (L) has the least irregularity or infrequency as it occurs only once or twice. Going by tonal frequency, we can conclude that the songs have the following overriding tonal pattern. H M L H. A closer look reveals that, apart from line one (L1) which has a final " $\mathrm{H}$ ", all other lines end with an $\mathrm{M}$ tone. A mid tone (MT) is a neutral tone which can go with either a high tone (HT) or a low tone (LT), resulting in tonal balancing. More interestingly, it indicates that the action to be taken are both ways. In the original song, both God and Christians have roles to play to achieve a goal. In the corrupted version, both the ruler and the ruled have roles to play to achieve a goal. The ' $\mathrm{M}$ ' tone ending is an indication that misdeeds or good deeds on either part can lead to an unknown and unexpected consequences which will generally be either negative or positive.

The tonal variation from ' $H$ ' to ' $M$ ' to ' $L$ ' back to ' $H$ ', to ' $M$ ' and ' $L$ ' makes the song melodious, musical and rhythmical.

Semantically, the two songs have (i) a proposition (ii) a confirmation (iii) a request or a rejection and a pledge of allegiance or abandonment. Politically speaking, the Civil Society Groups who composed songs of this nature see themselves as spokesmen for the general public against obnoxious policies of those in authority as well as critics of factors and forces threatening good standard of living of people in line with the position of Marxist theory adopted for this paper. However, protesters should always be conversant of the fact that use of language can be sometimes damaging and counterproductive, 
especially the use of èpè (curse) in their songs as a weapon of criticism against leaders who may have carried out certain wrong policies in error. Obviously, the expression ómí ló maa gbé o lọ ('you will drown in the ocean'), for a president who acted in error will not bring anything than disunity and chaos because, èpè (curse) in Yorùbá is not only spiritual, it is also magical. In other words, it is an expression of order which may spell doom for the person it is directed to. Although, the Civil Society Groups were enraged by the removal of subsidy as reflected in the use of the expression fọ wa jẹ ('disappointed us'), a new Yorùbá idiom which can also be interpreted connotatively as 'let us down', president Jonathan did not hesitate to prevent them from causing further havoc by using armed security personnel to disperse them from the park.

Similar to the aforementioned is another protest song used by some Civil Society Groups and many Nigerians in jubilation of the death of a former military Head of State, General Sani Abacha who died mysteriously in office on August $8^{\text {th }} 1998$ :

8) Álágbárá l'Ọlọ́run wà

Àlàgbàrà ní Jesù mi

Ọ́bá tó pa Sání Àbachà láì lo kóńdó

Ko ma sẹni tí kò le pá

Our God is a great God

Our Jesus is a enormous God

The king who killed Sani Abacha without cudgel

There is no one He cannot kill

This is also a corrupt coinage of one of the popular Christian songs of praise always rendered thus:

9) Álágbárá l'Ọlọ́run wà

Àlàgbàrà ní Jesù wa

Ọ́bá tó l'ayé at'ẹkún rẹ̀ ni ì káwọ́

Ko ma sóhun tí kò le șé

Our God is a mighty God

Our Jesus is a powerful God

The king who possesses the world and all that is in it

There is nothing he cannot do. 
The use of the above as a protest song exhibits a serious and clever creative ingenuity on the part of the protesters. In other to make the song sound like its Christian counterpart, the tonal scheme of the song is manipulated in a way that it is made nearly equal or even equal with that of the Christians. In other words, this ingenuity makes possible the similarity of syntactic structure in the two songs. The first two lines of the two songs are the same:

\section{Álágbárá l'Olórun wà \\ Àlàgbàrà ní Jesù wa}

Only the third and fourth line are corrupted without losing the tempo and rhythm of the original song:

Ọba tó pa Sání Abacha láilo kóńdó

Kò mà séni tí kò le pa

To achieve this, the syllable succession in the Christian song is equally maintained in the corrupted one. This makes the song sound like the real Christian song and at the same time appealing to the protesters and other people who could not but sing along with enthusiasm.

It should be stressed here also that indeed, Marxist theory used in this paper may have supported the fight for emancipation and liberation of the poor masses from the shackle of oppression (and even, condemnation and criticism of wrong government policies that are capable of inflicting excruciating pains on the poor masses) the theory does not in any way approve use of language(s) that are consequentially dangerous to the peace and stability of the society. In view of this, the third and fourth line of the above protest song is an expression of jubilation in the context of ridicule, mockery and derision and should be condemned in totality because it is against the Yoruba culture. In Yoruba culture, death is seen as a divine end of all and nobody is allowed to mock, deride or jubilate over a dead fellow irrespective of his undoing. Protesters were jubilating over 
Abacha's death because he was allegedly perceived as an absolute ruler whose regime was characteristic of alleged State killings which consequently brought pains to people. Since then, Civil Society Groups have been using the song for any leader whose policy is perceived to be anti-people.

Also, in another specific instance, when the Staff Unions of Adeniran Ogunsanya College of Education had internal wrangling with the College Management and the Lagos state Government on financial issues the following protest songs came alive:

10) Arungún ni wọ́n, wọn kií ș'èèyan an re Arungún ni wọ́n, wọn kii ș'èèyan an re Àwọn jẹúdújẹrá ti b'àkọoọẹ̀dí jẹ Arungún ni wọ́n wọn kií ṣ'èèyan an re

They are wastrels, they are not good persons They are wastrels they are not good persons The spendthrifts have destroyed AOCOED They are vandals, they are not good persons.

Phonologically speaking, the tone of the above which expresses financial fraud is typical of the traditional Yorùbá song always used at functions such as the traditional wedding, housewarming, naming, funeral and even as housewives' rivalry songs in terms of sound, rhythm and rhyme. Yorùbá being a syllable-timed language, rhythm at phonological level of the above protest song is based on syllable succession just like its traditional counterpart. In other words, the above protest song has the same number of syllables with the lines of any traditional song which have similar tones as the above. Also, in the above, the use of language is abusive and derogatory. It is highly derogatory to refer to someone, especially those in authority as Arungún ('wastre'l) and Jegúdújẹrá ('spendthrift'). Although, the allegations against Management of the College were monumental, the workers should have used songs that encapsulate all their grievances without the use of abuse or curse; they would have still gotten their internal issues resolved as it is today. During this period, AOCOED was in the news on daily basis. Below is another protest song rendered by the same Staff Unions in traditional mode: 
11) Oore ò ní sọnù lára wa Oore ò ní sọnù lára wa Àwá tí a wá bi Àlútà òní Oore ò ní sọnù lára wa

Goodness will not depart from us Goodness will not depart from us Those of us present at today's Aluta Goodness will not depart from us

12) Àwọn tóoré sọnù lára wọn Àwọn tóore sọnù lára wọn Àwọn ló ń jíwó ẹgbé òșiṣé Àwọn tóoré sọnù lára wọn

Those who have lost good value in them Those who have lost good value in them They are the one stealing union's funds Those who have lost good value in them

13) Wọn ò ní járá ayé jérò ọrun Wọn ò ní járá ayé jérò ọ̀run Àwọn tó ń jíwó ẹbẹ òșișé Wọn ò ní járá ayé jérò ọ̀run

They will neither be alive nor dead They will neither be alive nor dead Those who are stealing the union's funds They will neither be alive nor dead.

Phonologically, like the protest song previously analysed as having the same tone with its traditional counterpart, all the above equally have similar tonal schemes with the traditional ones. This is possible because of the similar syntactic structures of both the traditional songs and the protest songs. For instance, the traditional one is always rendered thus:

14) Oore ò ní sọnù lára wa

Oore ò ní sọnù lára wa Àwa tí a wá bi òkú Àbẹ̀kẹ Oore ò ní sọnù lára wa 


\begin{abstract}
Goodness will not depart from us
Goodness will not depart from us

Those of us present at Àbèkẹés funeral.

Goodness will not depart from us.
\end{abstract}

The second protest song (14) in this category is an expression of prayer and a build up to the subsequent ones which express curse and abuse exemplifying the same syntactic structure and tonal scheme with the above traditional song. The only expressions that are different are also of the same syllable Òkú Àbẹkẹ ('Àbẹkệ's funeral') and Àlútà òní ('today's struggle'). Àlútà can be connotatively interpreted as 'struggle' even though it is a Latin language. This first (9) of the protest songs in the traditional category is an expression of prayer, it is not damaging and can be used to press home the Union's demands instead of curse since Marxist theory which emphasizes criticism against wrong policy of government does not specify a particular language of criticism to be used.

The third (12) protest song expresses financial fraud in the context of abuse with the use of expression like 'loss or lack of good value and stealing of Union's funds' on the part of the College Management. These two expressions are not just derogatory and abusive to the personalities of the victims, they are equally damaging and destructive, looking at it from the concept of Omọlúàbí (good pedigree) in Yoruba culture. It should be stressed here also that apart from the fact that the song is short and brief it is also of similar tone with those analysed earlier. This makes it very easy to memorize and comprehend to those listening for the first time.

The last (13) song in this category expresses a unique but terrifying curse with the use of expression wọn ò ní jẹ ará ayé jẹ èrò ọrun ('they will neither be alive nor dead'). This type of curse is unique, terrific and horrific, its uniqueness is in the fact that it is $a$ double-edged curse which can be simply interpreted connotatively as between life and death. This is the height of all curses because if the curse comes to reality, the person referred to here is better dead than alive. As said earlier, curse in any form is magical and comes with order according to the Yoruba belief and so, curse of this nature should not be prescribed for anybody irrespective of his undoing. It is like wishing somebody a 
perpetually excruciating pain. Phonologically, this protest song also shares similar tone with others in traditional format.

\section{Inference}

From the foregoing, it can be deduced that protest songs, analysed in this paper are aspect of Yorùbá Literature which can be used to criticize wrong policies of government that are inimical to welfare of the citizens as clearly defined by Marxist theory adopted for this paper. It has also been established that some protest songs are not corrective measure, they are dangerous and susceptible to disruption of peace and stability of any society, especially those imbued with negative use of language that is tantamount to hate expression which almost set our country ablaze in the recent past. Expressions of these nature are curse, abuse, ridicule, derision and must be discouraged since it is not every time that wrong policy of government is deliberate or a calculated attempt to inflict pain on the citizens. Sometimes, the painful policies may be a panacea to attaining economic prosperity in line with the saying "no pain no gain".

The paper also reveals the creative ingenuity of the Civil Society Groups and other protesters for ingeniously recomposing the Christian songs to sooth their own purpose in such a way that expressions of praises in Christian songs are transmuted into curse, ridicule, derision, abuse and hate expressions. The paper equally emphasizes the creative ingenuity of the Civil Society Groups and other protesters for skillfully infusing new expressions into lines of some traditional Yorùbá songs as well as the transmogrification of certain expressions in lines of the Christian songs into the protest songs thereby appealing to listeners at first hearing like the original Christian songs.

Finally, the paper also reveals that the phonological linguistic strategy involved in the composition of the corrupt coinage of the Christian songs and the traditional songs analysed are used effectively to make the songs have similar rhythm, syntactic structure and syllable harmony with the Original songs so as to make them acceptable and appealing to their sympathizers. 


\section{Conclusion}

In conclusion, although, this paper is by no means exhaustive, it is hoped that it has succeeded in placing the Yorùbá political protest songs, especially those analysed in this paper in a proper position not only as an aspect of Yorùbá literature used for criticizing government positions but also to harness and channel public opinion on various issues affecting the society through government's obnoxious policies. It is hoped also that the Civil Society Groups and other protesters in this part of the world will acknowledge the fact that it is not every time that Government deliberately introduces bad policy, sometimes it is done in error and so, the use of language in their protest songs should not be the type that can cause mental and physical damage to those in authority; use of expressions like curse, abuse, ridicule and derision in protest songs are not only susceptible to disruption of peace and unity of the country, they are also not civilized enough to gain followers, respects and supports for any cause. If it is on record that the activisms of Martin Luther King Junior, Gandhi and Mandela effected desirable change in their different societies without negative use of Language, Civil Society Groups and other activists in this part of the world can as well do the same in their future engagements.

\section{References}

ADÉDĖ̀̀, S.O (2004) Nigerian Gospel Music: A Study of Its Style, Unpublished Ph.D. Thesis, Institute of African Studies, İbàdàn: University of İbàdàn.

ADÉGBiTÉ, A. (1994) "The Influence of Islam on Yorùbá Music", Oríta ìbàdàn Journal of Religious Studies vol. 1, No.2, 32-43.

ADÉYEMí, L. (2006) Tiộrì Lítírésọ ní Ėdè Yorùbá, İjèbú-òde: Șe bí o ti mọ Publications.

AgBÁJÉ, J.B (1995) A Literary Study of the Folksongs of the Èkitì People of Nigeria, Unpublished Ph.D. Thesis, University of İlọrin, Ìlọrin.

AJIBÁDÉ, A.O. (2011) "New wine in old cups: post-colonial Performance of Christian Music in Yorùbá Land", Studies in Word Christianity, 13(2), 105-126.

AKínLÀDÉ, K. (1985) Șàngbà Fọ́, İbàdàn: Paperback Publishers Limited.

ALÀBÁ, O. (1992) 'Ọgbọ́n Ìtọpinpin Ewì Yorùbá', Yorùbá Gbòde, vol. 1(8), 151-164. 
Dialectologia 24 (2020), 1-21.

ISSN: 2013-2247

BIER, H.U. (1956) "Yoruba Vocal music", Journal of the African Music, vol.1, No. 111, 23-28.

Bọ́LÁRìnWÁ, A.O. (2016) "Exemplification of political Conflict in selected Yoruba Novels", Journal of Yoruba Studies Association of Nigeria, vol. 8, No 2, 0.1, 133-159.

CAUDWELL, C. (1977) Illusion and Reality, London: Lawrence and Wishart.

EÉsúọlÁ, (2012) Behavioral Approach to political Protest: Analysis of Lagos, Unpublished Ph. D. dissertation, University of Lagos.

FÁLÉTí, A. (1969) Ọmọ Olókùn Ẹsin, London: University of London Press.

FINNEGAN, Ruth (1977) Oral poetry: Its Nature, significance and social context, London: Cambridge University press.

OGÚNDÈJì, P.A. (1991) "Introduction to Yoruba Oral Literature", Ibadan: Department of Adult Education, University of Ibadan.

OLÁBímtÁN, A. (1978) Bàbá Rere, Lagos: Macmillan Nigeria Publishers Limited.

OLÁNIÝYAN, T. (2004) Arrest the Music; Fela and his rebel arts and politics, USA: Indiana University Press.

OLÁTÚNJÍ, O. (1984) Features of Yorùbá Oral Poetry, Ìbàdàn: University Press Limited.

ORímóòGÙNJÉ, O.C. (2014) "The Symbolic Interpretation of Time and Space in the Yoruba Indigenous Healing System", in A. Ahmad Shehu (ed.), Bringing Our cultures Home: Festschrift for Bade Ajayi at. 70, Ibrin Chridamel Publishing House, 75-81.

OwóLABí, O. (1988) ọttẹ Nibò, Ìbàdàn: Vantage Publishers (Int) LTD. 